By the same author

MARKETING: AN INTRODUCTORY TEXT 
MARKETING NEW INDUSTRIAL PRODUCTS 


\section{MARKETING NEW INDUSTRIAL PRODUCTS}

Michael J. Baker

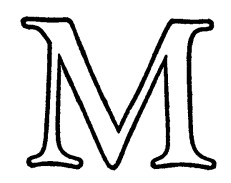


ISBN 978-1-349-02124-6 ISBN 978-1-349-02122-2 (eBook)

DOI 10.1007/978-1-349-02122-2

(C) Michael J. Baker 1975

Softcover reprint of the hardcover 1st edition 1975 978-o-333-15572-1

All rights reserved. No part of this publication may be reproduced or transmitted, in any form or by any means, without permission.

First published I 975 by THE MACMILLAN PRESS LTD

London and Basingstoke Associated companies in New York Dublin Melbourne Johannesburg and Madras

SBN $333 \quad 155726$ 
TO MY MOTHER 


\section{Contents}

Preface $\quad \mathbf{x i}$

I Innovation: Its Nature and Significance I

Introduction I

Innovation defined 2

Innovation and economic growth 5

New product development and corporate growth Io

The emergence of product differentiation as a

dominant competitive strategy II

The new product development dilemma I3

The nature and causes of product failure $\quad 17$

Resistance to change 2 I

2 Product Life Cycles and Diffusion Theory 24

Introduction $\quad 24$

The concept of the product life cycle 25

PLC's, diffusion and other exponential processes $\quad 26$

The pervasive nature of the S-shaped diffusion curve $\quad 29$

Resistance to change as a state of 'inertia' $\quad 3^{8}$

Resistance as a state of 'constant velocity' $\quad 39$

The theory as a basis for predicting diffusion $\quad 4^{\circ}$

'Social physics' and the validity of the laws of

diffusion

3 Factors Inflencing the Adoption of New Products $\quad 4^{8}$

Introduction $\quad 4^{8}$

The diffusion process $\quad 4^{8}$

'New products' as a function of perceived novelty 49

'New products' as a function of behavioural change $\quad 5^{\circ}$

'New products' as a function of perceived risk $\quad 50$

Continuous innovations $\quad 5^{\mathrm{I}}$

Dynamically continuous innovations $\quad 5^{\mathrm{I}}$

Discontinuous innovations $\quad 52$

Social systems defined $\quad 53$ 
Adoption defined 53

Stages in the adoption process $\quad 55$

Industrial innovation - current state of the art $\quad 5^{8}$

Industrial buying behaviour $\quad 59$

The economic research tradition $\quad 62$

The concept of adopter categories $\quad 65$

Innovational characteristics as an adoption

determinant

Relative advantage

Communicability $\quad 70$

Compatibility $\quad 70$

Complexity $\quad 70$

Divisibility 7 I

4 A Model of the New Product Adoption Process 73

$\begin{array}{ll}\text { Introduction } & 73\end{array}$

A rational/economic model of adoption $\quad 73$

The managerial view of the adoption process $\quad 75$

Résumé of possible causes of new product failure $\quad 76$

Implications of including an additional variable

in the model $\quad 79$

The Hudson Chemical case 81

5 The Influence of Organisational Structure

on Willingness to Innovate $\quad 84$

Introduction $\quad 84$

The concept of organisational climate $\quad 84$

The concept of organic and mechanistic organisational structures $\quad 88$

Co-ordination/integration and performance $\quad 90$

The Science and Industry Committee 95

The characteristics of technically progressive firms $\quad 98$

Statement of hypotheses 103

Relevance of the hypotheses $\quad$ I05

6 Indentifying the Early Buyer of New Industrial Products 109

Introduction I09

General considerations $\quad$ I09

Definition of boundaries for the field research $\quad$ I 3

Identifying suitable innovations $\quad$ I 4 
Contents

ix

The co-operating companies and their innovations II

USM Corporation

Cintimatic Division Cincinnati Milacron $\quad$ I I 7

Research methodology $\quad$ II9

Data analysis $\quad 120$

Analysis of the residuals $\quad 129$

Factor analysis 13 I

Research implications $\quad$ I37

Appendix A Tru-Line Printed-On Process I4 I

B Cintimatic NC Turret Drills $\quad$ I44

G Organizational Structure

Questionnaire

7 Strategies for Launching New Products I53

Introduction $\quad$ I53

The concept of limited strategic alternatives $\quad$ I53

New product development strategies $\quad$ I57

Push v. pull $\quad$ I60

Raw materials $\quad$ I60

Equipment $\quad 162$

Fabricated materials $\quad 162$

Supplies $\quad 162$

A normative approach to launching new industrial products $\quad$ I64

$\begin{array}{ll}\text { Summary } & \text { I69 }\end{array}$

8 Applying the Product Life Cycle Concept I 70

Introduction $\quad$ I 70

The PLC as a management tool 170

The role of marketing in new product development $\quad$ I 75

Conclusion I81

References $\quad 183$

Bibliography $\quad 192$

Index

208 


\section{Preface}

It is widely accepted that technological innovation embodied in new products and processes is a major source of economic growth. Despite concern over the pursuit of growth as an end itself, and a growing reaction against the more extreme forms of conspicuous consumption associated with such an emphasis, it is clear that growth is an essential prerequisite to an improvement in the standard of living of most of the world's population. However, it is also clear that while technological innovation results in a positive contribution in the aggregate this is considerably diminished by the failure of many new products to achieve commercial success in the market place. This book is both an inquiry into the causes of failure and a prescription for reducing its incidence.

It would seem that 'success' and 'failure' are usually measured in terms of elapsed time from market introduction to the achievement of some predetermined sales or profit criterion, e.g. the firm sets a sales target of 500 units by the end of two years. If sales are less than 500 units in two years then the project is a 'failure', if more than 500 units, a 'success'. If this is the case then it is clear that the speed with which a new product can gain acceptance is a critical determinant of whether it will be a success or otherwise.

In the marketing literature the sales history of a new project is usually represented as following an exponential pattern characterised as the product life cycle curve. In fact the S-shaped product life cycle curve corresponds very closely with the pattern observed for the manner in which a large number of different kinds of innovation diffuse or spread through a population of adopters. Further, the consistency of S-shaped diffusion curves suggests that there may be some underlying process which, once initiated, will proceed to some degree independently and with increasing speed - the 'bandwagon' effect. If this is the case, and 
we examine the proposition at some length, then a critical determinant of the speed of acceptance of a new product must be the innovator's ability to pre-identify those potential users with the greatest likelihood of early adoption.

Working on this hypothesis, the literature concerned with the diffusion of technological innovation (marketing new industrial products in the language of management) is explored at some length to see what light it can throw upon the identity of early adopters. Overall the evidence is scant and somewhat contradictory. In our view this is due to the emphasis upon economic determinants of adoption which dominates the research tradition concerned with industrial innovation to the virtual exclusion of any behavioural factors. Paradoxically, such studies as have been made of new consumer products are orientated almost entirely towards behavioural influences, to the almost complete neglect of physical and economic factors, and with no greater success in identifying early adopters.

It is our thesis that such identification must depend upon a combined economic-behavioural approach and we propose a simple model to this effect. The model itself was subjected to a preliminary test in an exploratory field survey in the United States, with favourable results in that broadly defined behavioural factors help explain the sequence in which firms adopted the two innovations studied.

Given the support of these findings we then review their implications when developing a launch strategy for new industrial products within a broader discussion of the firms overall marketing strategy.

Much of the work reported here is taken from the Doctoral dissertation which I submitted while at the Harvard University Graduate School of Business Administration and so owes much to the help and guidance of many people. In the first place, my stay at Harvard was only possible due to the award of a Marketing Teacher Fellowship made jointly by the Department of Education and Science and the Foundation for Management Education. For encouraging me to apply for this Fellowship I will always be grateful to Tom Gardiner, Head of Management Studies at Hull Colleges of Commerce and Technology and to Peter Dudley and Frank Edwards of Her Majesty's Inspectorate. 
Soon after arriving at Harvard I was encouraged to apply for admission to the Doctoral Program by Professors Warren Haynes and Ram Charan but was only able to do so because of a guarantee of continued support from the Foundation for Management Education. I extend my grateful thanks to $\mathrm{Mr}$ Philip Nind, the Director, the Trustees, and all those companies which so generously support the Foundation for their help.

In developing my research interests I received unstinted help from many members of the 'B-school' faculty but some must be singled out for special mention. Professor R. D. Buzzell first stimulated my interest in innovation when I was working for him as a Research Assistant at the Marketing Science Institute of which he was then Executive Director. Subsequently, Bob helped me develop my research proposal and also helped me obtain funds for my field survey from MSI with the support of Professors Jesse Markham and E. Raymond Corey. Both the latter gentlemen are distinguished scholars and honoured me by agreeing to serve on my thesis committee. In this they were joined by Professor Tom Robertson, well known for his own contributions in the field of innovation research. Such merits as this work may possess owe much to their help and guidance.

To the two companies, USM Corporation and Cincinnati Milacron, which provided the subjects of my study and the 143 anonymous respondents who made the survey possible, I also extend my thanks. These are also due to Al Silk (MIT) Kenneth Brown (IBM), Shirley O'Brien, Mike Polich (Harvard Computing Centre) and Bruce McKern for their assistance in analysing the data from the field research.

Scott Cunningham, for whom I worked as a Research Associate, must also receive special mention for scrupulously ensuring that these duties never impeded my own research interests.

As all authors readily acknowledge there are two other groups who deserve credit but certainly no blame. First there is my secretary Miss C. M. Paterson, who must wonder why she has to keep on retyping the same old material in a book on innovation, as must her assistants Mrs Mary Murphy and Miss Anne McMeekin. Finally, there is my family who have given me their unfailing support throughout. 
xiv

Preface

While all these people and organisations merit praise for their contributions to this book I retain the author's exclusive prerogative of full responsibility for all its faults.

Department of Marketing

M. J. Baker

University of Strathclyde

June 1974 